Review

\title{
Environmental Impact and Sustainability of Calcium Aluminate Cements
}

\author{
John F. Zapata ${ }^{1}$, Afonso Azevedo ${ }^{2}$ D, Carlos Fontes ${ }^{3}$, Sergio Neves Monteiro ${ }^{4}$ (D) and Henry A. Colorado ${ }^{5, *}, t^{(D)}$ \\ 1 Faculty of Engineering, Institución Universitaria de Envigado, Envigado 055422, Colombia; \\ jfzapata@correo.iue.edu.co \\ 2 Materials Engineering, Faculty of Engineering, State University of the Northern Rio de Janeiro, \\ Campos dos Goytacazes 28013-602, Brazil; afonso@uenf.br \\ 3 Materials Engineering, Faculty of Engineering, Universidade Estadual do Norte Fluminense, \\ Campos dos Goytacazes 28013-602, Brazil; vieira@uenf.br \\ 4 Department of Materials Science, Military Institute of Engineering-IME, Praça General Tibúrcio 80, Urca, \\ Rio de Janeiro 22290-270, Brazil; sergio.neves@ime.eb.br \\ 5 Composites Laboratory, Universidad de Antioquia (UdeA), Medellín 050010, Colombia \\ * Correspondence: henry.colorado@udea.edu.co \\ + Current address: Facultad de Ingeniería, Universidad de Antioquia, Bloque 20, Calle 67 No. 53-108, \\ Medellín 050010, Colombia
}

Citation: Zapata, J.F.; Azevedo, A.; Fontes, C.; Monteiro, S.N.; Colorado, H.A. Environmental Impact and Sustainability of Calcium Aluminate Cements. Sustainability 2022, 14, 2751 https://doi.org/10.3390/su14052751

Academic Editors: Mazen Alshaaer,

Slávka Andrejkovičová and

Asterios Bakolas

Received: 14 January 2022

Accepted: 22 February 2022

Published: 26 February 2022

Publisher's Note: MDPI stays neutral with regard to jurisdictional claims in published maps and institutional affiliations.

Copyright: (C) 2022 by the authors. Licensee MDPI, Basel, Switzerland. This article is an open access article distributed under the terms and conditions of the Creative Commons Attribution (CC BY) license (https:// creativecommons.org/licenses/by/ $4.0 /)$.

\begin{abstract}
This investigation presents a critical analysis of calcium aluminate cements (CAC), specifically associated with sustainability and environmental impact, and the potential of these cements to help solve certain worldwide problems. Areas of research include cements as recycling holding materials, sustainability, circular economy, production costs, and energy. This investigation summarizes the current trends, perspectives, and the main concerns regarding CAC. Detailed information about the materials and processes involved in CAC is also presented. First, a general search was made using the Carrot2 Workbench metasearch engine to identify possible thematic groups correlated with CAC, then a more in-depth and specialized search was done using the Scopus database. The results revealed that these materials have a lot of potential to help solve problems in the circular economy and suggest several exciting areas for conducting future research.
\end{abstract}

Keywords: cements; materials; sustainability; construction; civil engineering; phases

\section{Introduction}

Calcium aluminate cements (CAC) are classified as hydraulic cements and are mostly used in applications involving extreme environments, which include refractories [1], acid resistant requirements, and fast setting cements. These materials are currently the subject of research on topics like property improvement, durability and more friendly manufacturing processes. CAC are manufactured industrially from mixtures of limestone and materials with a high content of $\mathrm{Al}_{2} \mathrm{O}_{3}$ (bauxites, laterites and alumina obtained via the Bayer process, among other materials) [2]. CAC are considered eco-cements due to the reduced carbon emissions created during their production. They also have diverse applications due to their impressive early age strength and enhanced durability in harsh environments [3].

The main mineral phases present in CACs are calcium mono aluminate (CA), calcium dialuminate $\left(\mathrm{CA}_{2}\right)$, dodecalcium heptaaluminate $\left(\mathrm{C}_{12} \mathrm{~A}_{7}\right)$ and alpha-alumina $\left(\alpha-\mathrm{Al}_{2} \mathrm{O}_{3}\right)$. All CAC properties depend only on their mineralogical phase composition $[2,4]$.

The specific gravity of CACs varies between 3000 and $3250 \mathrm{~kg} / \mathrm{m}^{3}\left(3\right.$ and $\left.3.3 \mathrm{~g} / \mathrm{cm}^{3}\right)$, and is largely controlled by the iron content. The apparent density is typically between 1.12 and $1.74 \mathrm{~g} / \mathrm{cm}^{3}$. The specific surface area measured by the British Standard method can vary between 2.500 and $4.000 \mathrm{~cm}^{2} / \mathrm{gr}$. The properties of the constituent minerals of CACs as well as their typical chemical composition are shown in Table 1. 
Table 1. Properties of the constituent minerals of CAC.

\begin{tabular}{|c|c|c|c|c|c|c|c|c|}
\hline \multirow{2}{*}{ Mineral } & \multicolumn{4}{|c|}{ Chemical Composition (wt\%) } & \multirow{2}{*}{$\operatorname{Tm}\left({ }^{\circ} \mathrm{C}\right)$} & \multirow{2}{*}{$\begin{array}{l}\text { Density } \\
\left(\mathrm{g} / \mathrm{cm}^{3}\right)\end{array}$} & \multirow{2}{*}{ Crystal Structure } & \multirow{2}{*}{$\begin{array}{l}\text { Formation Enthalpy } \\
(\mathrm{kJ} / \mathrm{mol})\end{array}$} \\
\hline & $\mathrm{CaO}$ & $\mathrm{Al}_{2} \mathrm{O}_{3}$ & $\mathrm{Fe}_{2} \mathrm{O}_{3}$ & $\mathrm{SiO}_{2}$ & & & & \\
\hline $\mathrm{C}$ & 99.8 & - & - & - & 2570 & 3.32 & Cubic & - \\
\hline $\mathrm{C}_{12} \mathrm{~A}_{7}$ & 48.6 & 51.4 & - & - & 1405-1495 & 2.69 & Cubic & - \\
\hline CA & 35.4 & 64.6 & - & - & 1600 & 2.98 & Monoclinic & -2323 \\
\hline $\mathrm{CA}_{2}$ & 21.7 & 78.3 & - & - & $1750-1765$ & 2.91 & Monoclinic & -4023 \\
\hline $\mathrm{C}_{2} \mathrm{~S}$ & 65.1 & - & - & 34.9 & 2066 & 3.27 & Monoclinic & - \\
\hline $\mathrm{C}_{4} \mathrm{AF}$ & 46.2 & 20.9 & 32.9 & - & 1415 & 3.77 & Orthorhombic & - \\
\hline $\mathrm{C}_{2} \mathrm{AS}$ & 40.9 & 37.2 & - & 21.9 & 1590 & 3.04 & Tetragonal & - \\
\hline $\mathrm{CA}_{6}$ & 8.4 & 91.6 & - & - & 1830 & 3.38 & Hexagonal & - \\
\hline $\mathrm{Al}_{2} \mathrm{O}_{3}$ & - & 99.8 & - & - & 2051 & 3.98 & Rhombohedral & \\
\hline
\end{tabular}

The main hydraulic phase in all CACs is the CA phase. Of all the influencing factors, temperature is the most important since hydration products depend heavily on the curing temperature [5-11]. According to several studies, the initial hydration product that emerges within the temperature range of 0 to $15^{\circ} \mathrm{C}$ is predominantly $\mathrm{CAH}_{10}$ (Monocalcium aluminate decahydrate), while between $15^{\circ} \mathrm{C}$ and $35^{\circ} \mathrm{C}$ the predominant phases are $\mathrm{CAH}_{10}$, $\mathrm{C}_{2} \mathrm{AH}_{8}$ (Dicalcium aluminate octahydrate) of hexagonal morphology, and amorphous $\mathrm{AH}_{3}$ (Gibbsite). Above $35^{\circ} \mathrm{C}$, the major phase formed is C3AH6 (Katoite) [4,12-15]. CA hydration is primarily responsible for the early development of resistance, while CA2 hydration occurs after the main CAC hydration reaction has already been exceeded [16]. Refs. [17-19] shows some properties of the hydrated phases (Table 2).

Calcium aluminate cements (CAC) are mainly used in the refractory industry. They are also mixed with other cements such as Portland cement to create products in the ceramic industry, especially in construction [4,14,20-24]. Can recycled materials be used for the manufacture of calcium aluminate cements? How do calcium aluminate cement products fit into a circular economy? What relationship is established between the energy sector and the production of calcium aluminate cements? How are calcium aluminate cements being implemented within additive manufacturing? These are important questions in a world where factors that affect the environment and energy contribute to global warming.

Table 2. Densities, molar masses of the hydrated phases, and enthalpy of formation.

\begin{tabular}{cccc}
\hline Hydrated Phase & Density $\left(\mathbf{g} / \mathbf{c m}^{\mathbf{3}}\right)$ & Molar Mass $\mathbf{( g / m o l )}$ & Formation Enthalpy (kJ/mol) \\
\hline CAH10 & 1.72 & 338.1 & - \\
C2AH8 & 1.96 & 358.2 & $-5433[25,26]$ \\
AH3 & 2.44 & 156.0 & $-2578[25]$ \\
C3AH6 & 2.52 & 378.3 & - \\
\hline
\end{tabular}

Figure 1 shows the SEM images of the main hydrated phases of $\mathrm{CAC}$ at $20{ }^{\circ} \mathrm{C}$, (a) CAH10, and (b) C2AH8. The laminar structure is very clear, with all thicknesses below $0.5 \mu \mathrm{m}$.

Concrete based on Portland cement is the most widely used material in the world and its massive production is responsible for approximately 5 to $8 \%$ of global manmade $\mathrm{CO}_{2}$ emissions [27]. $\mathrm{CO}_{2}$ emissions are mainly due to energy consumption during the manufacturing process and decarbonization of limestone during clinker manufacturing. These emissions could be reduced by replacing clinker methods with inorganic minerals from industrial wastes such as slag, fly ash, and silica fume, or by using CAC despite its much smaller scale production compared to Portland cement [28]. The study and use of $\mathrm{CAC}$ is therefore very valuable to reduce global environmental problems. 

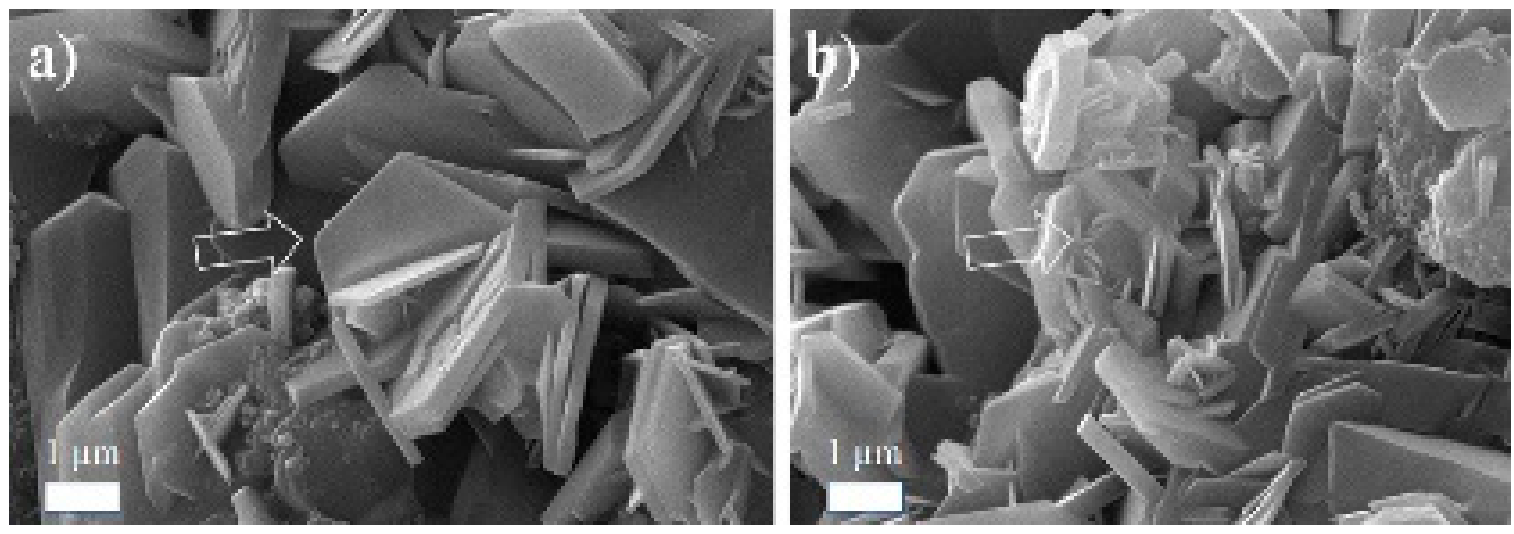

Figure 1. SEM of hydrated phases of $\mathrm{CAC}$ at $20{ }^{\circ} \mathrm{C}$, (a) $\mathrm{CAH}_{10}$, and (b) $\mathrm{C}_{2} \mathrm{AH}_{8}$.

The generation of $\mathrm{CO}_{2}$ is an important consideration in the manufacture of cement. Thus, it is pertinent to know which mechanisms are involved in the process in order to try to reduce such emissions. 3D printing is a revolutionary new process that impacts many sectors, including medicine and construction. Additive manufacturing (AM) is a process whereby materials are joined to make objects from a 3D model, layer upon layer [29-32], which minimizes the materials wasted. Due to the importance of these latter two areas, they are included in this review to see how much they have been researched already. The value of the other areas included in this review needs no further justification.

This research shows how investigations into CAC are helping to solve its most significant environmental issues. In order to understand and classify all this research, a general search was first carried out using the meta search engine Carrot2 Workbench. Carrot2 Workbench is an open-source search results clustering engine. After that, an exhaustive search was performed using the Scopus database, and the information found there was then analyzed.

\section{Materials and Methods}

A general search was initially carried out using the Carrot2 Workbench metasearch engine and the keywords Calcium Aluminate Cement. The initial search employed the following sources: etools web search and the K-mean algorithm (base line algorithm, bagof-words labels). A second search was done using the etools web search and the Lingo algorithm (well-described flat clusters).

After that, a deeper and more specialized search was conducted in the Scopus database, with keywords provided by Carrot2 Workbench and complemented by others that were more specific to CACs and the environment, hydration, high temperature, refractory, Portland cement. The Scopus database search was performed with the keywords shown in Figure 2a.

\section{a)}

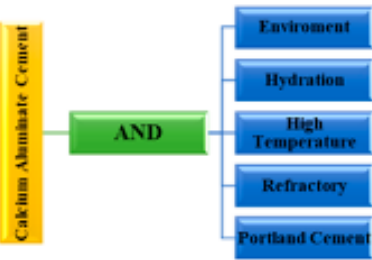

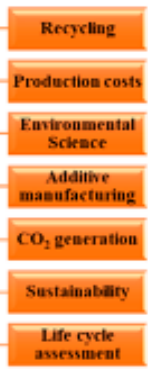

b)

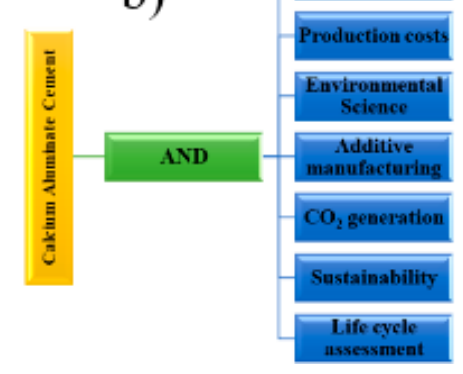

Figure 2. Scopus database search for specific areas. (a) CACs and the environment, hydration, high temperature, refractory, Portland cement (b) CACs and recycling, productions costs, environmental science, additive manufacturing, $\mathrm{CO}_{2}$ generation, sustainability, life cycle assessment. 
Subsequently, the documents found for specific areas, recycling, productions costs, environmental science, additive manufacturing, $\mathrm{CO}_{2}$ generation, sustainability and life cycle assessment, related to CACs and the environment were analyzed, as shown in Figure $2 \mathrm{~b}$. Finally, the studies found in the last stage were described.

\section{Results}

The search was conducted using the Carrot2 Workbench with the keyword calcium aluminate cement—Source: etools web search—algorithm: Lingo (well-described flat clusters.). The search found 118 documents in general areas, and 33 documents in clusters (see Figure 3). The few articles found are dispersed over 33 clusters, where $40 \%$ (48 documents) focus on clusters such as Portland cement and CAC (see Figure 3). This high dispersion of very few articles means that a common thread in the studies cannot be established and practically every cluster is an area of research to explore.

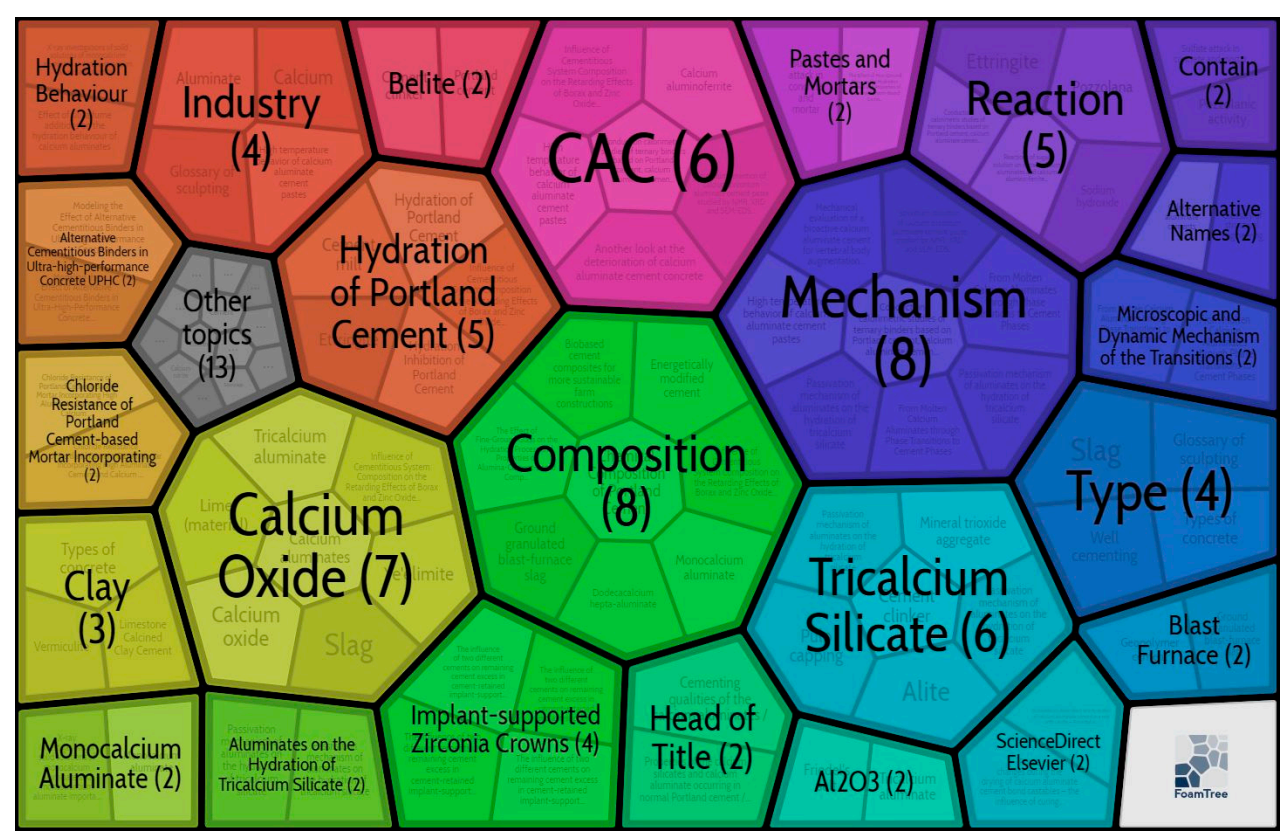

Figure 3. Carrot2 Workbench database search.

The search using Carrot2 Workbench with the keyword calcium aluminate cementSource [33,34]: etools web search-algorithm: K-mean (base line algorithm, bag-of-words labels), showed 58 documents in related areas and 19 documents in clusters (see Figure 4). This search found more specific clusters but also showed that there are fewer articles and an increased dispersion. According to the metasearch engine, there are not enough studies to establish a common thread of work in a specific area. No cluster is presented as a developed area. On the contrary, each cluster is open to new research, as seen in Figure 4 [33,34].

A deeper and more specialized search was performed in the Scopus database, with the keywords given in Figure 2a. The search in Scopus found that the most commonly investigated factors associated with CAC are the hydration process, refractoriness, high temperature behavior, and the mixture of CAC + Portland cement. A total of 2832 documents were found. It can be established from this review that the factors associated with the most investigated CACs are the hydration process, high temperature behavior, refractoriness, and mixing with Portland cements. A quantification of the type and number of studies carried out in relation to these factors is presented in Figure 5 and in Table 3. 


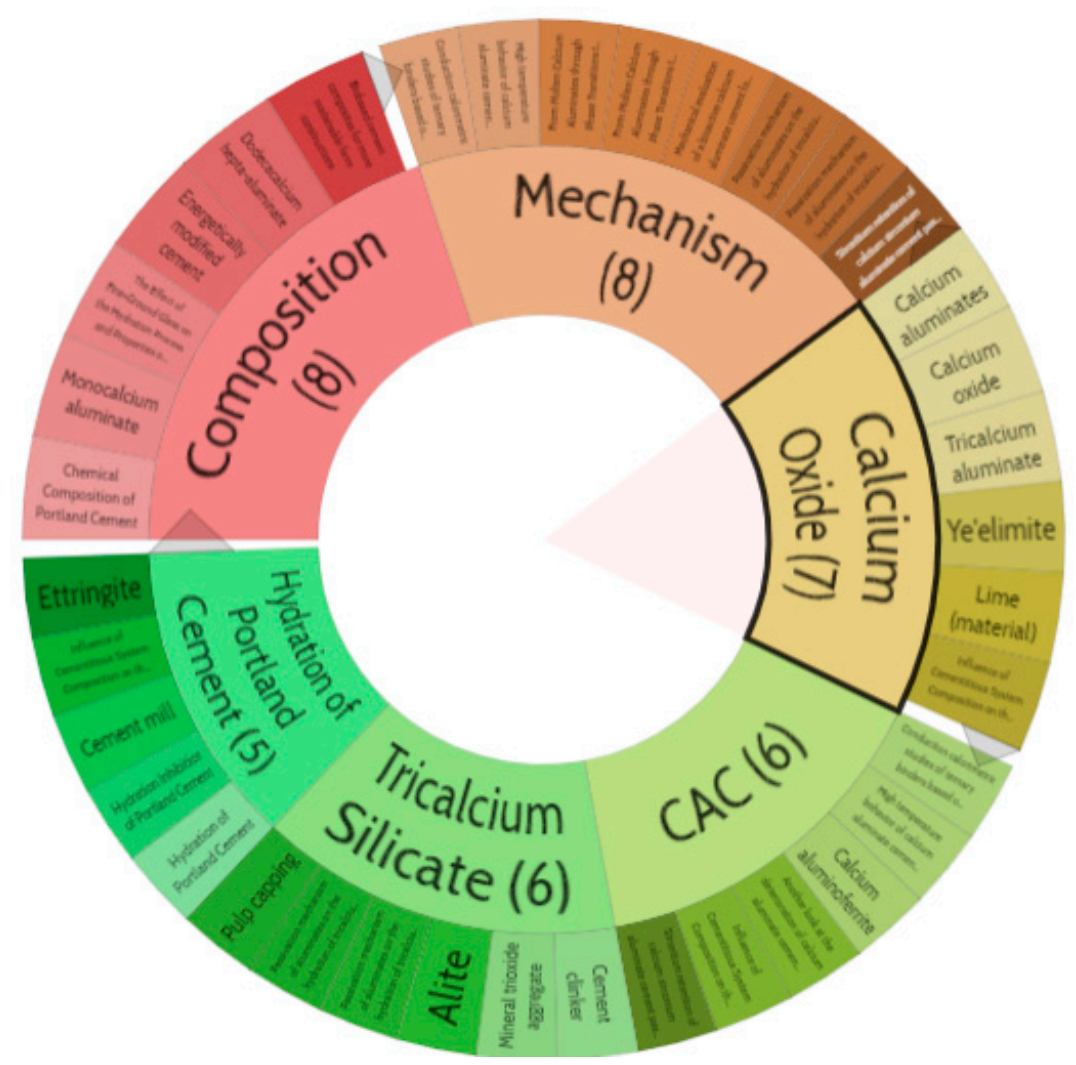

Figure 4. Carrot2 Workbench database search for specific areas.

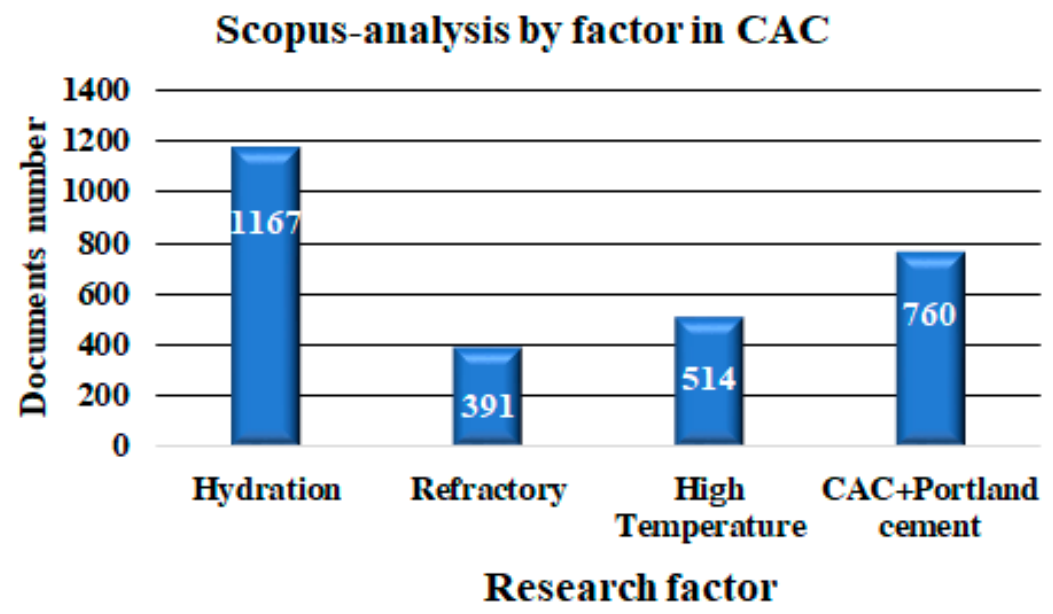

Figure 5. Documents organized by research factor in the Scopus database.

Table 3. Types of documents organized by CAC study factor.

\begin{tabular}{ccccccc}
\hline & Article & $\begin{array}{c}\text { Conference } \\
\text { Paper }\end{array}$ & Review & $\begin{array}{c}\text { Conference } \\
\text { Review }\end{array}$ & Book Chapter & $\begin{array}{c}\text { Production Interval } \\
\text { (In Years) }\end{array}$ \\
\hline Hydration & 939 & 189 & 27 & 10 & 2 & $1957-2022$ \\
High Temperature & 412 & 78 & 11 & 8 & 5 & $1946-2022$ \\
Refractory & 298 & 69 & 16 & 5 & 19 & $1946-2022$ \\
Portland Cement + CAC & 579 & 137 & 16 & 10 & 18 & $1975-2022$ \\
\hline
\end{tabular}

It is clear that the hydration process is the most widely investigated topic in CAC, followed by topics related to refractories, behavior at high temperature, and the CAC + Portland Cement mixtures (see Figure 5). 
The bibliographic search was performed using the Scopus database until November 2022, in which 112 documents were found for the environmental areas shown in Figure 6. The search in the specialized Scopus database shows very few studies. It can be divided into 7 clusters, which indicates a high dispersion, and a common thread or an area of research cannot be defined. Therefore, each cluster shown in Figure 3 and Table 4 represent an area of investigation to explore.

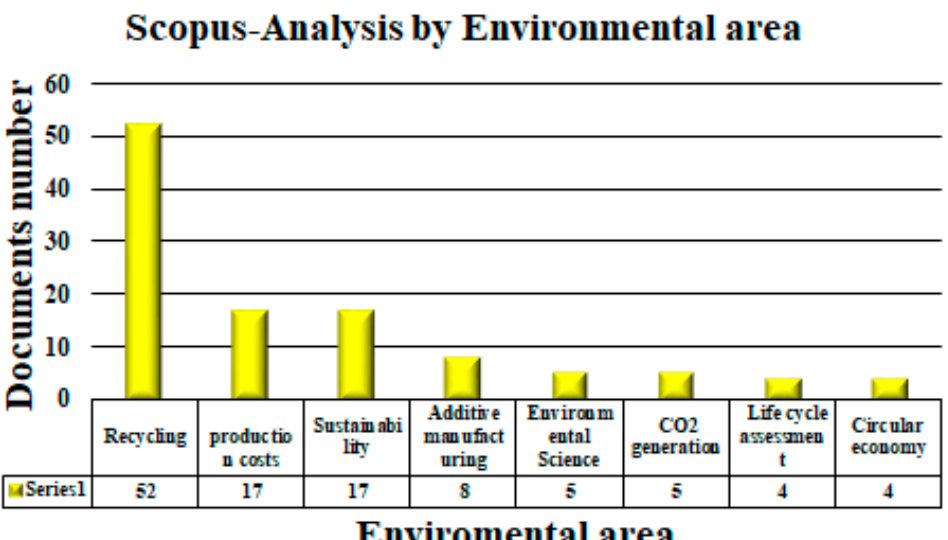

Enviromental area

Figure 6. Scopus database search for environmental area.

Table 4. Types of documents organized by environmental cluster.

\begin{tabular}{ccccccc}
\hline & Article & $\begin{array}{c}\text { Conference } \\
\text { Paper }\end{array}$ & Review & $\begin{array}{c}\text { Conference } \\
\text { Review }\end{array}$ & Book Chapter & $\begin{array}{c}\text { Production Interval } \\
\text { (In Years) }\end{array}$ \\
\hline Recycling & 37 & 7 & 1 & 4 & 3 & $1995-2022$ \\
Production costs & 13 & 3 & 1 & 0 & 0 & $1995-2021$ \\
Environmental Science & 3 & 2 & 0 & 0 & 0 & $2001-2020$ \\
Additive manufacturing & 3 & 1 & 1 & 1 & 2 & $2010-2021$ \\
CO $_{2}$ generation & 4 & 1 & 0 & 1 & 0 & $2011-2021$ \\
Sustainability & 10 & 4 & 1 & 0 & 1 & $2007-2021$ \\
Circular economy & 4 & 0 & 0 & 1 & 0 & $2017-2021$ \\
Life cycle assessment & 1 & 2 & 0 & 1 & 0 & $2014-2021$ \\
\hline
\end{tabular}

Table 4 shows the type of document organized according to environmental clusters, like the years the articles were published. As shown in Table 4, from 112 documents, only 70 articles were found in all areas. In Circular Economy, four articles were registered, and in Life Cycle Assessment, only one was found. In Environmental Science and Additive Manufacturing, three articles per area were found. In Sustainability, 10 articles were found, and in $\mathrm{CO}_{2}$ Generation, four articles were found. The most widely investigated areas are Production Costs and Recycling.

\section{Discussion}

The revision of the state of the art shows incipient development in the literature related to calcium aluminate cements and the environment, such as $\mathrm{CO}_{2}$ Generation, Sustainability, Additive Manufacturing, Environmental Science, Production Costs, Recycling, and Circular Economy. There is therefore a well-defined research area that can be developed for each topic. Furthermore, this review suggests five emerging research areas for CACs, as shown in Figure 7. 


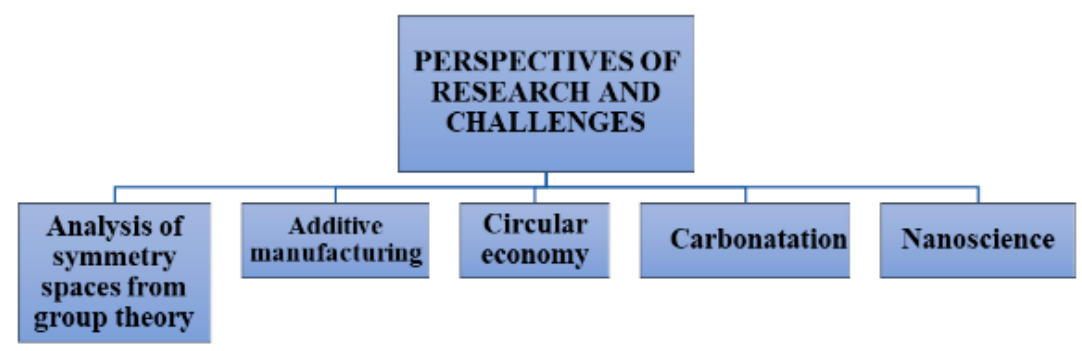

Figure 7. Perspectives of research and challenges.

\subsection{Analysis of Symmetry Spaces from Group Theory-Nanoscience}

The fundamental chemical interactions that control the structure and performance of cements have been investigated in detail. However, the complex and crystallographic nature of the phases that form in hardened cements makes it difficult to obtain detailed information on the local structure, reaction mechanisms, and kinetics [35-38]. Solid state nuclear magnetic resonance spectroscopy could solve the key atomic structural issues within these materials in combination with the proper use of X-ray diffraction. The X-ray diffraction should focus on unveiling the crystalline symmetry spaces, in order to set out promising lines of research. The research could generate models using highly advanced designs of new materials using knowledge of their quantum behavior and their proper combination with various suitable nano materials suggested by the theoretical analyzes.

\subsection{Additive Manufacturing}

Additive manufacturing technologies (also known as 3D printing) have expanded rapidly in various industrial sectors, including aerospace, automotive, medical, architecture, arts and design, food and construction. Transition from visualization and prototyping stages to functional and real parts replacement opens up more design possibilities. Among the various AM applications, building and construction is a very promising large-scale area for development and will be included in the coming manufacturing revolution. However, there are obvious challenges and risks to integrating AM into large-scale construction, such as construction and reinforcement regulation. Progress in commercialization is advancing at a slow pace since only a few large-scale 3DP trials for construction can be found in the literature [39-41]. The use of CACs to generate AM-friendly mixtures is therefore a virgin and unexplored research area with great prospects for success.

\subsection{Circular Economy}

Although CACs can potentially be used to benefit the environment, including the use of waste as aggregates in concrete manufacturing, neutralization of reactive substances, and the storage of hazardous substances, no studies were found that investigate the use of CACs within the circular economy production chain.

Searching in the Scopus database using the keywords calcium aluminate cement + circular economy did not produce any results. This reveals that little work has been carried out on the management of solid waste generated from manufactured products based on CAC. Therefore, new processes using CAC-based waste and the circular economy would be of great interest to industry, and would potentially have a significant environmental impact.

\subsection{Carbonatation Process}

CAC paste is known to react with atmospheric carbon dioxide. Carbonation causes numerous chemical-mechanical changes in the cement paste, but can also improve properties of the cement material [42-45]. For these reasons, the active use of carbonation as a tool to manipulate the properties of CAC-based materials is a very promising research area that could potentially improve fiber-reinforced cementitious compounds and promote concrete recycling and immobilization of waste. 
The carbonation of CACs has been investigated in order to find adequate conditions to improve the mechanical properties of CACs. However, the very specific manufacturing conditions of CAC paste, such as water/cement ratios greater than 0.4 , hydration in the presence of alkalis and hydration in a high-humidity atmosphere [44,46], produce a paste with very poor mechanical performance for construction and refractories. However, these pastes do have a high $\mathrm{CO}_{2}$ absorption capacity. Therefore, hydrating $\mathrm{CAC}$ in conditions that are unfavorable to its mechanical properties could drastically increase its $\mathrm{CO}_{2}$ absorption capacity, which could be used to reduce $\mathrm{CO}_{2}$ contamination elsewhere. After these pastes are saturated with $\mathrm{CO}_{2}$, they could be included in the circular economy as a construction material. While no research has been found in this area, it would be an excellent topic to review. The research presented here describes advances in sustainability and many other specific and important topics related to the circular economy of CAC. However, the lack of progress in these areas is quite evident considering the social demands on modern construction materials. Moreover, the required approaches demand a rethinking of the material and process in the circular economy. The process needs to be not only reused but also optimized to reduce energy, water and material waste. From an academic, innovation and production point of view, this technological lag opens up new opportunities to produce a CAC that fits in with the advances of the 21st century. Such research is important because it would pave the way for not only significant progress towards a more sustainable CAC, but also reveal the limitations and opportunities in the area for a real modern CAC material.

\section{Analysis by Specific Area}

\subsection{Analysis by Environmental Area}

After refining the search and restricting only to CAC + environment, the Scopus database shows 112 articles distributed by cluster as shown in Table 4 . Below is a description of each article found.

\subsubsection{CAC + Recycling}

A search with the keywords, calcium aluminate cement and recycling (CAC + recycling) in the Scopus database yielded 52 documents only 37 articles were found. The number of documents produced per year is presented in Figure $8 \mathrm{a}$. It can be seen that the highest production was in the last 3 years, with 28 works presented.

The use of CAC can effectively mitigate the expansion of the alkali-silica reaction (ASR) of alkali activated cement mortars (AAC) incorporating glass cullet (GC) as fine aggregates, but the mechanism is unclear [47]. P. He, et al. [47]. present a systematic study on the exploration of the underlying mechanism and to determine the safe use of GC in AAC to maximize the possibility of recycling glass waste in construction materials.

They found that the ASR expansion of the alkali activated glass mortars was more than $1000 \mu \varepsilon$ after 1 day of alkaline immersion, when using GC and the incorporation of CAC decreases the expansion to less than $1000 \mu \varepsilon$, even after 14 days of immersion alkaline, decreased by $20 \%$. This result occurs because the aluminium in CAC was incorporated into the AAC matrix with tetrahedral and octahedral units. Increasing the CAC content increases the tetrahedral unit that required more $\mathrm{Na}$ ions to balance the excess charge, which caused the alkalinity of the pore solution to decrease as did the expansion of ASR.

B. Zhang, et al. [48] feature a way to incorporate recycled glass materials into AACbased pastes/mortars. The GC waste was used to replace natural aggregates and the glass waste powder (GP) was used to partially replace conventional precursors such as blast furnace slag (GGBS). Using the developed technology, recycled AAC-based mortars can be produced with a 28-day compressive strength of approximately $40 \mathrm{MPa}$. The AAC mortar mixes showed good resistance to high temperatures, retaining more than $50 \%$ of the original resistance after $2 \mathrm{~h}$ of exposure at $800{ }^{\circ} \mathrm{C}$. The experimental results also showed that the damaging expansion caused by the alkaline silica (ASR) reaction between alkali and residual GC in AAC mortars could be successfully controlled by using additional sources of aluminum such as CAC. 

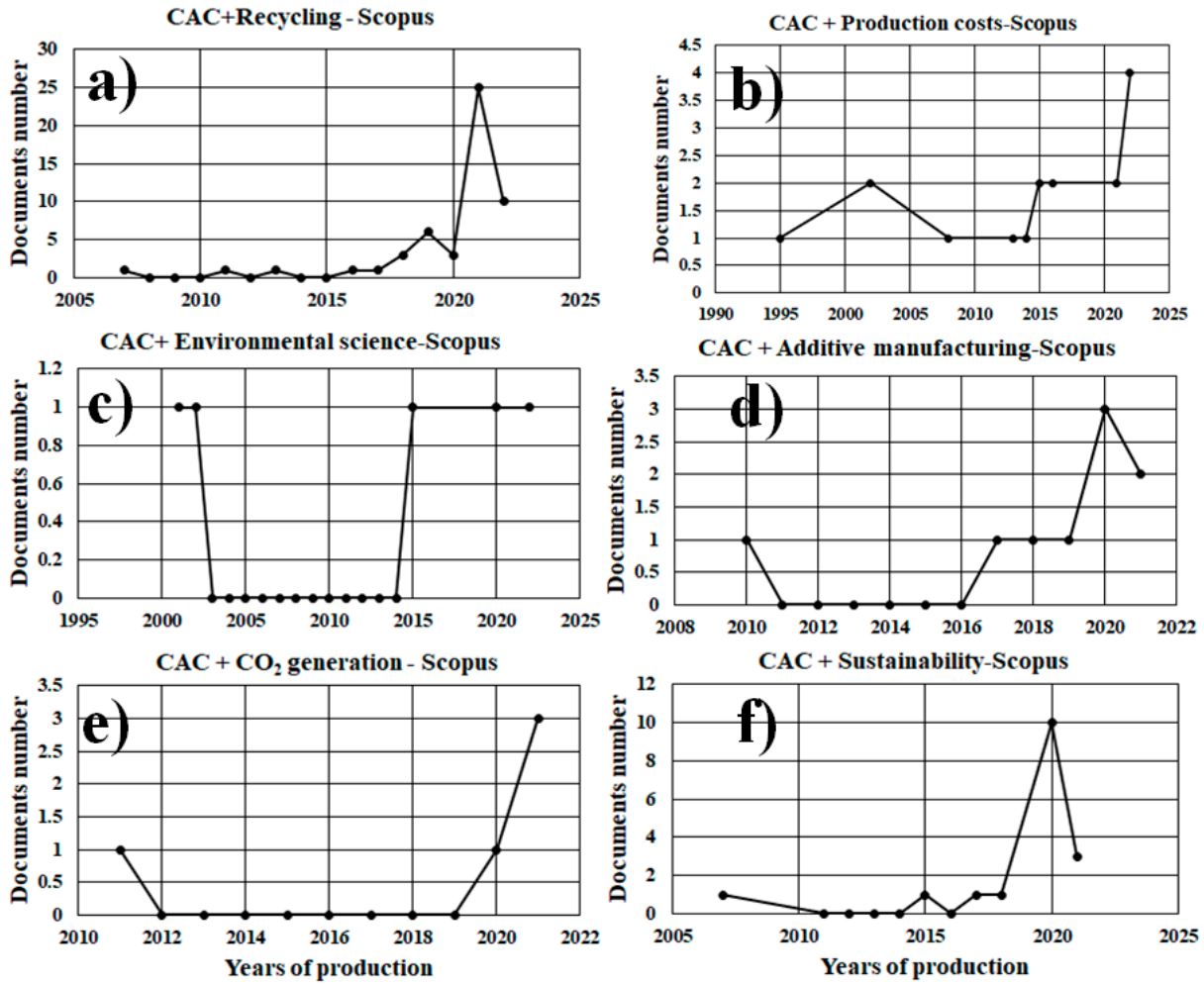

Figure 8. Scopus database search for calcium aluminate cement and recycling (CAC + recycling). (a) CAC + Recycling (b) CAC + Production Costs (c) CAC + Environmental Science (d) CAC + Additive Manufacturing (e) $\mathrm{CAC}+\mathrm{CO}_{2}$ Generation (f) $\mathrm{CAC}+$ Sustainability.

Chang, et al. [48] also investigated the compressive strength, drying shrinkage and ASR expansion of AAC mortars using GC as aggregates and GP to partially replace GGBS as the precursor. They noted that mortars using GC as an aggregate, replacing GGBS with GP decreased compressive strength, and mortars using sand as an aggregate, showed severe drying shrinkage, while replacement of sand by GC could significantly decrease drying shrinkage.

The alkali activated GGBS mortars using GC as an aggregate showed great expansion after alkaline immersion. When GP is used to partially replace GGBS, the expansion was significantly reduced. The replacement of $15 \%$ of GGBS by CAC could further decrease the expansion. The optimal proportion of the AAC mix developed in this study was that the mortars incorporated $15 \%$ CAC, $10 \%$ GGBS, and $75 \%$ GP, could meet stipulated mechanical requirements and durability requirements for bulkhead applications.

W. Panpa, et al. [49] produced a visible light active compound, $\mathrm{Ag}{ }_{2} \mathrm{O}-\mathrm{Ag} / \mathrm{CAC} / \mathrm{SiO}_{2}$, by loading an aqueous solution of silver salt onto the hydrated CAC coating layer in a porous $\mathrm{SiO}_{2}$ sphere. The slight hydration condition of the cement induced the formation of $\mathrm{Ag}_{2} \mathrm{O}$ precipitates in situ on the cement surface which partially decomposed into metallic Ag after drying and appropriate heat treatment at $200^{\circ} \mathrm{C}$ to improve both $\mathrm{Ag}_{2} \mathrm{O}$ decomposition and crystallinity.

The photo catalytic activity of the compound $\mathrm{Ag}_{2} \mathrm{O}-\mathrm{Ag} / \mathrm{CAC} / \mathrm{SiO}_{2}$ (calcined at $200{ }^{\circ} \mathrm{C}$ ), evaluated under irradiation with UV light and visible light through the photo decomposition of CHP in water, quantified by HPLC, was two times greater than that $\mathrm{Ag}_{2} \mathrm{O}-\mathrm{Ag} / \mathrm{CAC} / \mathrm{SiO}_{2}$ compound (dried at $45^{\circ} \mathrm{C}$ ), and capable of completely decomposing $\mathrm{CHP}$ in $5 \mathrm{~h}$. Furthermore, the photo stability of the $\mathrm{Ag}_{2} \mathrm{O}-\mathrm{Ag} / \mathrm{CAC} / \mathrm{SiO}_{2}$ photocatalyst remained unchanged during five recycling tests.

S.K.S. Hossain and P.K. Roy [50] formulated a nano-lakargiite system (NL) $\left[\mathrm{CaZrO}_{3}\right]$ for formless refractories. The NL powder formulation is made from a solution mixture, which is easily capable of recycling by-products. Scrap shells were used as a source of $\mathrm{CaO}$ 
for the preparation of NL. They reached at $1100^{\circ} \mathrm{C}$, the single-phase orthorhombic crystal structure with the Pnma space group of nano $\mathrm{CaZrO}_{3}$ (average crystallite size $\sim 19 \mathrm{~nm}$ ). The formulation involved replaced CAC with $\mathrm{NL}$ was heat treated at $1600{ }^{\circ} \mathrm{C}$, resulting in properties that matched by the different advanced bonding systems of high alumina refractory molds, therefore, achieving good densification, heat resistance, and thermal shock resistance for NL bonded refractory molds.

H. Al-musawi, et al. [51] studied the time-dependent transport properties and shrinkage performance of smooth and fiber-reinforced rapid-setting mortars for repair applications, in two single mixes of Steel-Fiber-Reinforced Concrete (SFRC). They found that CSA cement mixes have much lower shrinkage values (about 220 and 365 microspheres) compared to CAC mixes (about 2690 and 2530 microspheres), but most of the shrinkage in these formulations were autogenous. However, the fibers reduced the drying shrinkage of the CAC mixes by approximately $12 \%$.

$\mathrm{H}$. Al-musawi, et al. [52] investigated the flexing performance of fast-setting mortar mixes made with two types of commercial cement, calcium sulfonate cement and CAC, for thin concrete repair applications. They performed three-point bending tests on samples of smooth steel-fiber reinforced (FRC) concrete containing $45 \mathrm{~kg} / \mathrm{m}^{3}$ of recycled clean steel fibers to characterize the bending performance of notched and notched prisms at different ages, ranging from one hour to one year. They found that recycled fibers improve both the flexural strength and toughness of FRC prisms.

One of the best methods of recycling waste in the construction sector is to use it in the preparation of concrete or mortar. S.T. Yildirim, et al. [53] used recycled concrete aggregates and bottom ash as aggregates in the mortar. They used CAC as a binder to improve fire resistance. They investigated flexural and compressive strength, dry unit weight, water absorption, capillary action, thermal conductivity, thermal resistance, and costs, following a Taguchi method for internal cure (IC), the amount of cement, and the aggregate ratio as parameters. They found that IC does not have enough positive effect on mortars. Choosing the appropriate type of cement is believed to be effective. The process of obtaining resistance for $\mathrm{CAC}$ is quite fast and water had a negative rather than a positive effect. It is believed that IC water should have increased the amount of water mix. The increase in the amount of CAC has a positive effect because the dosage of cement in the mortars is kept low and the durability with respect to temperature is maintained.

P. Kulu, et al. [54] recycled the niobium slag, separating the metallic $\mathrm{Nb}$ and the mineral ballast - calcium aluminate. Preliminary tests of cement to use the main product as a binder or substitute for cement confirmed its potential for use in the production of construction materials. P. Ogrodnik, et al. [55] investigated sanitary ceramic waste as an addition to concrete. Six concrete mixes on Portland cement and CAC were designed with various aeration mix contents. They found that the compressive strength is adequate for concrete containing ceramic aggregate and CAC at high temperatures.

M. Nematzadeh, et al. [56] investigated the compressive behaviour of concrete containing fine recycled refractory brick aggregate, CAC fibers, and polyvinyl alcohol (PVA) in an acidic environment, motivated because earthquake-induced structural debris and other factors cause destruction and problems related to the damaging effects of acidic environments. They found that samples containing CAC along with PVA fibers have an adequate corrosion response against acid attacks, while samples containing fine refractory brick aggregate showed quite unsatisfactory performance in this regard.

M. Nematzadeh and A. Baradaran-Nasiri [57] investigated the compression stressstrain behaviour of recycled aggregate concrete. Different levels of replacement of conventional fine aggregate by recycled particles from used refractory bricks were used $(0$, $25,50,75$ and $100 \%$ volume replacement level) in two groups, one containing PC and the other containing CAC. After exposure to elevated temperatures (110, 200, 400, 600, 800 and $1000{ }^{\circ} \mathrm{C}$ ), significant degradation occurred for most of the mechanical properties for concrete containing ordinary cement at $400{ }^{\circ} \mathrm{C}$ and for concrete containing aluminate cement 
at $110^{\circ} \mathrm{C}$. Higher fine brick refractory aggregate contents improved concrete compression behaviour at higher temperatures.

A. Baradaran-Nasiri and M. Nematzadeh [58] investigated the use of recycled aggregate produced by crushing firebricks. Samples were separated based on CAC and OPC with replacement ratios of $0,25,50,75$ and $100 \%$ of fine aggregate of refractory brick instead of natural sand. After exposing the samples to temperatures of 110, 200, 400, 600, 800, and $1000{ }^{\circ} \mathrm{C}$, it was found that the addition of refractory brick and the CAC improve the residual strength of the concrete up to twice, at the temperature of $800{ }^{\circ} \mathrm{C}$.

R. Stonys, et al. [59] studied the waste from mineral wool (dome dust-CD) and its possible reuse in the production of CAC-based refractory concrete, replacing the silica addition with $\mathrm{CD}$. It was found that $\mathrm{CD}$ can be used for the production of refractory concrete. Í. Navarro-Blasco, et al. [60] studied waste foundry sand (WFS) in CAC mortars with a replacement level of $50 \%$. Compared to OPC mortars, the use of CAC showed several advantages, improving compressive strength and retention of toxic metals.

L.J. Fernández, et al. [61] studied the recycling of crystalline solar cells incorporated into cement matrices. The hydration process of a mixture of CAC and photovoltaic solar cell waste was analyzed, founding that the presence of up to $5 \%$ solar cell residue in cement matrices does not result in new hydration products that are different from those derived from normal CAC hydration. Furthermore, the developed material can be considered an expansive cement mix because it releases $\mathrm{H} 2$ in the early stages. The presence of residues causes a decrease in mechanical resistance and an increase in the total porosity of this material, although, it could be used for applications such as thermal insulation.

Chen et al. [62], showed that CAC had an excellent immobilization efficiency of potentially toxic elements in fly ash from municipal solid waste incineration.

\subsubsection{CAC + Production Costs}

A search with the keywords, calcium aluminate cement, and production costs (CAC + production costs) in the Scopus database yielded 17 results. The number of documents produced per year is presented in Figure $8 \mathrm{~b}$. The low production in this topic can be observed in the last 25 years.

M. Erans, et al. [63] oriented their research to the production of improved sorbents, motivated by the fact that the calcium loop $(\mathrm{CaL})$ is a $\mathrm{CO}_{2}$ capture technology and a fundamental problem for the commercialization of these technologies is to maintain a high level of sorbent reactivity during the long-term cycle, to mitigate the decrease in carrying capacity. A great strength of CaL compared to other carbon capture technologies is the synergy with the cement industry, due to the use of spent sorbent as Clinker raw material.

M. Erans, et al. [63] investigated limestone doped with $\mathrm{HBr}$ through a particle surface impregnation technique and granules prepared from limestone and CAC. These were tested in a $25 \mathrm{kWth}$ dual fluidized bed pilot scale reactor to understand their capture performance and mechanical stability under realistic $\mathrm{CaL}$ conditions and the spent sorbent was subsequently used as a raw material to make cement. It was found that $\mathrm{HBr}$-doped limestone showed better performance in terms of mechanical strength and stability of $\mathrm{CO}_{2}$ absorption compared to that of granules prepared from limestone and $\mathrm{CAC}$, and that the cement produced has characteristics and performance similar to that of commercial CEM I cement. This demonstrates the advantages of using spent sorbent as a raw material for cement manufacturing and shows the benefits of synthetic sorbents in $\mathrm{CaL}$ and the end-use suitability of spent sorbents for the cement industry. It can be concluded from the work of M. Erans, et al. [63], the feasibility of using various practical techniques to improve the performance of $\mathrm{CaL}$ on a pilot scale, and more importantly, it shows that commercial grade cement can be manufactured at from the lime product of this technology.

Abolhasani et al. [3] discusses the results of a comprehensive study incorporating rice husk ash (RHA) in CAC concrete to limit the phase transition of CAC hydration product and stabilize its long-term properties. The findings indicate that, at 90 days, the mechanical 
strengths of the mixes containing RHA were higher than those of the control mix, with the maximum improvement occurring at the substitution percentage of $5 \%$.

\subsubsection{CAC + Environmental Science}

A search with the keywords, calcium aluminate cement and Environmental science (CAC + Environmental science) in the Scopus database yielded 5 results. The number of documents produced per year is presented in Figure 8c. This reveals almost no production in the last 20 years.

L. Xu, et al. [64] investigated setting times, mechanical strength and drying shrinkage ratio of mixed OPC and CAC systems (less than $25 \%$ ). They found that with CAC, the set times of combined systems are shortened; the compressive strength first increases slightly (peaks with $6 \%$ calcium aluminate cement) and then decreases significantly. T.T. Akiti Jr, et al. $[65,66]$ developed a calcium-based sorbent to desulfurize the hot carbon gas, this led to the development of a spherical granule-like material, which has a limestone-based core enclosed in a strong support layer. Strong granules are prepared by incorporating some CAC into the core and a larger amount into the shell, along with the limestone.

The granules are prepared by a two-step granulation method, followed by steam curing and heat treatment. It was found that the granules are capable of absorbing relatively large amounts of hydrogen sulfidic at high temperature (e.g., 1150-1200 K) that can be regenerated by a cyclical oxidation and reduction process.

Secondary aluminum dross (SAD) is a dangerous pollutant as well as a valuable resource. About $95 \%$ SAD is disposed by stockpiling on the spot due to its complex composition and technical limitations, causing severe ecological damage and public health threat [67]. Mingzhuang et al. [67] developed a new green process for the preparation of ultrafine and high-whiteness $\mathrm{Al}(\mathrm{OH})_{3}$ from SAD. This phase can then be used as a high-strength cementitious material by mixing it with CAC.

\subsubsection{CAC + Additive Manufacturing}

A search with the keywords, calcium aluminate cement and Additive manufacturing (CAC + Additive manufacturing) in the Scopus database returned 10 results. The number of documents produced per year is presented in Figure $8 \mathrm{~d}$. This reveals almost zero production in the last 10 years.

P. Shakor, et al. [68] They discuss a methodology for replacing the typical powders currently used in $3 \mathrm{D}$ printing to make it possible to use printed samples in construction applications. They found that the highest compressive strength $(14.68 \mathrm{MPa})$ is obtained for samples that were first cured in water and then oven dried for one hour at $40{ }^{\circ} \mathrm{C}$, compared to samples that were cured without drying at $40{ }^{\circ} \mathrm{C}(4.81 \mathrm{MPa})$. Therefore, the post-processing technique has a significant and effective impact on the resistance of printed samples. P. Shakor, et al. [69] developed a mixture of CAC through a $150 \mu \mathrm{m}$ sieve and OPC for the Z-Corporation 3D Printing Process (3DP). This cement mix was mixed, and the resulting compound powders were printed with a water-based binder using a Z-Corporation 3D printer. In addition, lithium carbonate was added to some samples to reduce the setting time of the cement mix. The maximum compressive strength of the cubic samples for cementitious 3DP was $8.26 \mathrm{MPa}$ at the $170 \%$ saturation level for both the shell and the core. The minimum porosity obtained was $49.28 \%$ at the saturation level of $170 \%$ and $340 \%$ for the cover and the core, respectively.

V. Antonovich, et al. [70] carry out a review on the use of nano technologies in the manufacture of refractory concretes and some other cementitious materials, examining the influence of nanostructure formation on the bonding material on the properties of refractory concretes. In one case, investigations were carried out using two-component bonding materials (sodium silicate solution mixed with dicalcium silicate) and three-components (sodium silicate solution mixed with dicalcium silicate plus calcium aluminate cement). Cement refractory concretes with mullite aggregates, micro silica, and hybrid and simple deflocculant additives (Castament FS20 polycarboxylate ether and sodium tripolyphos- 
phate) was studied, finding that the three-component bond material hardens as opposed to the two-component material, since one of the bonding components (combination of sodium silicate and dicalcium silicate solution) hardens very quickly and affects the hydration process of the other component, CAC. This has a powerful impact on the entire structure of the material. The application of nanotechnology in the manufacture of refractory concretes has increased the compressive strength three times, from $55 \mathrm{MPa}$ to $165 \mathrm{MPa}$. CACs can be effectively used as an accelerator for PC hydration for the purpose of layered extrusion. Das, et al. [71] established that CAC mixed with a source of calcium sulfate could be a better alternative than using CAC alone.

\subsection{5. $\mathrm{CAC}+\mathrm{CO}_{2}$ Generation}

The search with the keywords, calcium aluminate cement and $\mathrm{CO}_{2}$ generation $(\mathrm{CAC}+$ $\mathrm{CO}_{2}$ generation) in the Scopus database returned five results. The number of documents produced per year is presented in Figure 8e. This reveals almost no production in the last 9 years.

S. Bharati, et al. [72] developed, with a sustainable approach, a low cost mouldable for low temperature applications using steelmaking slag as raw materials. The ladle slag generated after the secondary steelmaking process was used in the $50-70 \%$ range as a complete source of $\mathrm{CaO}$ to develop a $\mathrm{CAC}$. The slag was used as a $100 \%$ replacement for the limestone and partial replacement of the $\mathrm{Al}_{2} \mathrm{O}_{3}$ source in the cement. In this way, it was possible to eliminate the $\mathrm{CO}_{2}$ emission associated with the dissociation of the limestone during the clinker manufacturing process. The castable was prepared using primary steel slag as an aggregate and slag cement was developed as a binder. The CA and CA2 phases were detected as primary phases in the slag cement and gehlenite and mayenite as secondary phases.

The slag was used as a $100 \%$ replacement for the limestone and a partial replacement for the $\mathrm{Al}_{2} \mathrm{O}_{3}$ source in the cement. Therefore, it was possible to eliminate the $\mathrm{CO}_{2}$ emission associated with the dissociation of limestone during the clinker manufacturing process. The castable was prepared using primary steel slag as an aggregate, and slag cement was developed as a binder. CA and CA2 were formed as the primary phases in the slag cement, with the Gehlenite phases. Slag cement with a slag content of $60 \%$ exhibited superior strength compared to commercial medium purity CAC. In addition, the crush strengths of $110^{\circ} \mathrm{C}$ and $1000{ }^{\circ} \mathrm{C}$ were found to be better for casting slag cement than commercial cement. Therefore, it was possible to develop a green mold using by-products from the steel manufacturing process that would not only help reduce the carbon footprint, but also reduce manufacturing costs.

\subsubsection{CAC + Sustainability}

A search with the keywords, calcium aluminate cement and Sustainability (CAC + Sustainability) in the Scopus database returned 17 results. The number of documents produced per year is presented in Figure $8 \mathrm{f}$. This reveals almost zero production in the last 8 years.

M. Giroudon, et al. [73] analyze the deterioration mechanisms of different binders focusing on the impact of the binding nature on the medium (biochemical composition) during digestion. Binders with a favorable composition for chemically aggressive media were tested: slag cement (CEM III/B), CAC and alkaline metakaolin-based material (MKAA), and a reference binder: OPC (CEM I). Under the explored conditions, biodeterioration mainly led to carbonation of the cement pastes.

Alternative cementitious materials (MCAs) are receiving increasing attention worldwide, but there is a lack of knowledge about the resistance of these materials against the intrusion of harmful ions. Furthermore, current accelerated test methods that measure ion diffusion under an electric field are not reliable when comparing binders with very different pore solution chemistry. M.K. Moradllo and M.T. Law [74] solve these problems by using laboratory transmission X-ray microscopy (TXM) and micro-X-ray fluorescence 
imaging $(\mu \mathrm{XRF})$ to perform real-time measurements of ion diffusion in paste samples and mortar for five commercially available ACMs and a OPC. They compared the apparent rate of ion diffusion, quantified the change in the rate of ion diffusion over time, and gave an idea of ionic binding. It was found after 42 days of ion exposure that samples made with calcium aluminate cement had the lowest rate of ion penetration, while samples with activated alkali cement and calcium sulfoaluminate had the highest rate of ion penetration. Portland cement had an ion penetration level that was between these two. Furthermore, both alkali activated and calcium sulfoaluminate samples showed a decrease in penetration rate over time. These measurements are important to quantify the sustainability of MCAs, better justifying their uses where durability is a concern, and guiding to future durability tests for these promising materials.

It is well-known that cement production represents 1.65 billion metric tons of annual global $\mathrm{CO}_{2}$ emissions [75], making it one of the largest contributors to global $\mathrm{CO}_{2}$ emissions. One way to reduce $\mathrm{CO}_{2}$ emissions associated with concrete construction is using alternative cementitious materials and binders (ACMs), such as calcium sulfoaluminate, calcium aluminate, and alkali activated binders. These materials often require lower production temperatures than OPCs and have lower calcium contents, reducing the emissions associated with the $\mathrm{CO}_{2}$ released by calcium carbonate during calcination. Most ACMs are not new materials, but the past uses have been primarily limited to small-scale applications, such as pavement repairs, and there is little field experience regarding their long-term durability in heavily travelled structures, such as pavements and bridge decks. L.E. Burris, et al. [76] present promising results after the first year, of an effort by the U.S. Department of Transportation.

\subsubsection{CAC + Life Cycle Assessment}

The search with the keywords, calcium aluminate cement and Life cycle assessment (CAC + Life cycle assessment) in the Scopus database returned four results.

Henry-Lanier, et al. [77] evaluated the environmental footprint for the CAC, calculated according to the guidelines defined in the ISO 14,040 and 14,044 standards for Life Cycle Analysis (LCA). After focusing on the methodology and data used, summarizes the intrinsic carbon footprint and energy consumption of CAC production from the cradle to the factory gate. Other data drawn from the LCA literature and databases are provided in this document to give a comparative view of the data for CAC. This document presents results to compare different refractory systems (monolithic and shaped) used for a selected application, showing the intrinsic opportunity to reduce the carbon footprint of specific refractory applications by using monolithic refractories containing calcium aluminate. The conclusions suggest that the use of LCA can be a powerful tool to optimize the types of refractory products and reduce the overall environmental impact of refractories throughout the life cycle of use.

\section{Conclusions}

- The products of CAC that are recycled as sanitary waste, among other wastes, serve as an aggregate for Portland cement mortars, improving their mechanical properties and behavior at high temperature.

- CAC maximizes the possibility of recycling glass waste in the manufacture of construction materials. Research on CAC waste in relation to its application within a circular economic structure is incipient.

- The manufacture of CAC mortars using mineral wool waste has shown improved resistance to compression and resulted in the stabilization and neutralization of toxic metals.

- $\quad$ CAC proved to be a good additive to Portland cement for the manufacturing of 3D printing mixes with very good mechanical properties.

- There is great potential in CAC research to help solve global issues, such as the use of CAC in $3 \mathrm{D}$ printing, the immobilization of solid waste and the manufacture of new 
nanostructured materials, as well as the carbonation of CAC pastes at low and high temperature.

Author Contributions: Conceptualization, H.A.C. and J.F.Z.; methodology, A.A.; validation, J.F.Z., C.F., S.N.M. and H.A.C.; investigation, J.F.Z., S.N.M. and A.A.; writing-original draft preparation, H.A.C., J.F.Z., S.N.M., C.F.; writing-review and editing, A.A. and J.F.Z.; supervision, H.A.C.; project administration, A.A. and C.F.; funding acquisition, J.F.Z., C.F. and H.A.C. All authors have read and agreed to the published version of the manuscript.

Funding: The APC was funded by Military Institute of Engineering-IME.

Data Availability Statement: All data will be available upon request of the reviewers and editors.

Conflicts of Interest: Conflicts of interest/Competing interests (None). Availability of data and material (Total). Consent for publication (All authors agree).

\section{References}

1. Abolhasani, A.; Samali, B.; Aslani, F. Physicochemical, mineralogical, and mechanical properties of calcium aluminate cement concrete exposed to elevated temperatures. Materials 2021, 14, 3855. [CrossRef]

2. Scrivener, K. Calcium aluminate. Adv. Concr. Technol. Set 2003, 1, 2.

3. Abolhasani, A.; Samali, B.; Dehestani, M.; Libre, N.A. Effect of rice husk ash on mechanical properties, fracture energy, brittleness and aging of calcium aluminate cement concrete. Structures 2022, 36, 140-152.

4. Zapata, J.F.; Gomez, M.; Colorado, H.A. Structure-property relation and Weibull analysis of calcium aluminate cement pastes. Mater. Charact. 2017, 134, 9-17. [CrossRef]

5. Zapata, J.F.; Gomez, M.; Colorado, H.A. High Temperature Cracking Damage of Calcium Aluminate Cements. In Proceedings of the TMS Annual Meeting \& Exhibition; Springer: Berlin/Heidelberg, Germany, 2018; pp. 553-563.

6. Zapata, J.F.; Gomezc, M.; Colorado, H.A. Characterization of two calcium aluminate cement pastes. In Advances in High Temperature Ceramic Matrix Composites and Materials for Sustainable Development; Wiley-American Ceramic Society: Hoboken, NJ, USA, 2017; pp. 491-503.

7. Zapata, J.F.; Gomez, M.; Colorado, H.A. Calcium Aluminate Cements Subject to High Temperature. Adv. Mater. Sci. Environ. Energy Technol. VI 2017, 262, 97.

8. Zapata, J.F.; Gomez, M.; Colorado, H.A. Cracking in Calcium Aluminate Cement Pastes Induced at Different Exposure Temperatures. J. Mater. Eng. Perform. 2019, 28, 7502-7513. [CrossRef]

9. Ukrainczyk, N.; Matusinovic, T.; Kurajica, S.; Zimmermann, B.; Sipusic, J. Dehydration of a layered double hydroxide-C2AH8. Thermochim. Acta 2007, 464, 7-15. [CrossRef]

10. Cardoso, F.A.; Innocentini, M.D.M.; Akiyoshi, M.M.; Pandolfelli, V.C. Effect of curing time on the properties of CAC bonded refractory castables. J. Eur. Ceram. Soc. 2004, 24, 2073-2078. [CrossRef]

11. Capmas, A.; Menetrier-Sorrentino, D.; Damidot, D. Effect of temperature on setting time of calcium aluminate cements. In Calcium Aluminate Cements; Taylor \& Francis: New York, NY, USA, 1990; pp. 65-80.

12. Bushnell-Watson, S.M.; Sharp, J.H. On the cause of the anomalous setting behaviour with respect to temperature of calcium aluminate cements. Cem. Concr. Res. 1990, 20, 677-686. [CrossRef]

13. Lee, W.E.; Vieira, W.; Zhang, S.; Ahari, K.G.; Sarpoolaky, H.; Parr, C. Castable refractory concretes. Int. Mater. Rev. 2001, 46, 145-167. [CrossRef]

14. Barnes, P.; Bensted, J. Structure and Performance of Cements; CRC Press: Boca Raton, FL, USA, 2014; ISBN 1482295016.

15. Da Luz, A.P.; Braulio, M.d.A.L.; Pandolfelli, V.C. Refractory Castable Engineering; FIRE, Federation for International Refractory Research and Education: Baden-Baden, Germany, 2015; ISBN 3872640046.

16. Mercury, J.M.R.; AZAa, A.; Turrillas, X.; Pena, P. Hidratación de los cementos de aluminatos de calcio (Parte I). Boletín Soc. Española Cerámica Vidr. 2003, 42, 269-276. [CrossRef]

17. Scrivener, K.L.; Capmas, A. Calcium aluminate cements. In Lea's Chemistry of Cement and Concrete; Wiley: Hoboken, NJ, USA, 1998; pp. 713-782.

18. Hewlett, P.; Liska, M. Lea's Chemistry of Cement and Concrete; Butterworth-Heinemann: Oxford, UK, 2019; ISBN 978-0-08-100773-0.

19. Midgley, H.G. Quantitative determination of phases in high alumina cement clinkers by X-ray diffraction. Cem. Concr. Res. 1976, 6, 217-223. [CrossRef]

20. Scrivener, K.L.; Cabiron, J.-L.; Letourneux, R. High-performance concretes from calcium aluminate cements. Cem. Concr. Res. 1999, 29, 1215-1223. [CrossRef]

21. Bentsen, S. Effect of microsilica on conversion of high alumina cement. In Calcium Aluminate Cements; Chapman and Hall: London, UK, 1990; p. 294.

22. Parker, K.M. Refractory calcium aluminate cements. Trans. Br. Ceram. Soc. 1982, 82, 35-42.

23. Antonovič, V.; Kerienè, J.; Boris, R.; Aleknevičius, M. The effect of temperature on the formation of the hydrated calcium aluminate cement structure. Procedia Eng. 2013, 57, 99-106. [CrossRef] 
24. Zapata, J.F.; Colorado, H.A.; Gomez, M.A. Effect of high temperature and additions of silica on the microstructure and properties of calcium aluminate cement pastes. J. Sustain. Cem. Mater. 2020, 1-27. [CrossRef]

25. Lothenbach, B.; Matschei, T.; Möschner, G.; Glasser, F.P. Thermodynamic modelling of the effect of temperature on the hydration and porosity of Portland cement. Cem. Concr. Res. 2008, 38, 1-18. [CrossRef]

26. Matschei, T.; Lothenbach, B.; Glasser, F.P. Thermodynamic properties of Portland cement hydrates in the system $\mathrm{CaO}_{-} \mathrm{Al}_{2} \mathrm{O}_{3}-$ $\mathrm{SiO}_{2}-\mathrm{CaSO}_{4}-\mathrm{CaCO}_{3}-\mathrm{H}_{2}$ O. Cem. Concr. Res. 2007, 37, 1379-1410. [CrossRef]

27. Gartner, E. Industrially interesting approaches to "low- $\mathrm{CO}_{2}$ " cements. Cem. Concr. Res. 2004, 34, 1489-1498. [CrossRef]

28. Bizzozero, J. Hydration and Dimensional Stability of Calcium Aluminate Cement Based Systems. Available online: https: / /infoscience.epfl.ch/record/202031 (accessed on 1 January 2022).

29. Rahimi, M.; Esfahanian, M.; Moradi, M. Effect of reprocessing on shrinkage and mechanical properties of ABS and investigating the proper blend of virgin and recycled ABS in injection molding. J. Mater. Process. Technol. 2014, 214, 2359-2365. [CrossRef]

30. Prendergast, M.E.; Burdick, J.A. Recent advances in enabling technologies in 3D printing for precision medicine. Adv. Mater. 2020, 32, 1902516. [CrossRef] [PubMed]

31. Browne, M.P.; Redondo, E.; Pumera, M. 3D printing for electrochemical energy applications. Chem. Rev. 2020, 120, 2783-2810. [CrossRef] [PubMed]

32. Distler, T.; Boccaccini, A.R. 3D printing of electrically conductive hydrogels for tissue engineering and biosensors-A review. Acta Biomater. 2020, 101, 1-13. [CrossRef]

33. Stefanowski, J.; Weiss, D. Carrot 2 and language properties in web search results clustering. In Proceedings of the International Atlantic Web Intelligence Conference, Madrid, Spain, 5-6 May 2003; Springer: Berlin, Heidelberg, 2003; pp. $240-249$.

34. Weiss, D.; Osinski, S. A concept -driven algorithm for clustering search results. IEEE Intell. Syst. 2005, $20,48-54$.

35. Walkley, B.; Provis, J.L. Solid-state nuclear magnetic resonance spectroscopy of cements. Mater. Today Adv. $2019,1,100007$. [CrossRef]

36. Redaoui, D.; Sahnoune, F.; Heraiz, M.; Raghdi, A. Mechanism and kinetic parameters of the thermal decomposition of gibbsite Al $(\mathrm{OH}) 3$ by thermogravimetric analysis. Acta Phys. Pol. A 2017, 131, 562-565. [CrossRef]

37. Šesták, J. Ignoring heat inertia impairs accuracy of determination of activation energy in thermal analysis. Int. J. Chem. Kinet. 2019, 51, 74-80. [CrossRef]

38. Ondro, T.; Húlan, T.; Vitázek, I. Non-isothermal kinetic analysis of the dehydroxylation of kaolinite in dynamic air atmosphere. Acta Technol. Agric. 2017, 20, 52-56. [CrossRef]

39. Al Rashid, A.; Khan, S.A.; Al-Ghamdi, S.G.; Koç, M. Additive manufacturing: Technology, applications, markets, and opportunities for the built environment. Autom. Constr. 2020, 118, 103268. [CrossRef]

40. Savolainen, J.; Collan, M. How Additive Manufacturing Technology Changes Business Models?-Review of Literature. Addit. Manuf. 2020, 32, 101070. [CrossRef]

41. Oliveira, J.P.; Santos, T.G.; Miranda, R.M. Revisiting fundamental welding concepts to improve additive manufacturing: From theory to practice. Prog. Mater. Sci. 2020, 107, 100590. [CrossRef]

42. Šavija, B.; Luković, M. Carbonation of cement paste: Understanding, challenges, and opportunities. Constr. Build. Mater. 2016, 117, 285-301. [CrossRef]

43. Ashraf, W. Carbonation of cement-based materials: Challenges and opportunities. Constr. Build. Mater. 2016, 120, 558-570. [CrossRef]

44. Park, S.M.; Jang, J.G.; Son, H.M.; Lee, H.-K. Stable conversion of metastable hydrates in calcium aluminate cement by early carbonation curing. J. $\mathrm{CO}_{2}$ Util. 2017, 21, 224-226. [CrossRef]

45. Tonoli, G.H.D.; dos Santos, S.F.; Joaquim, A.P.; Savastano, H., Jr. Effect of accelerated carbonation on cementitious roofing tiles reinforced with lignocellulosic fibre. Constr. Build. Mater. 2010, 24, 193-201. [CrossRef]

46. Fernández-Carrasco, L.; Rius, J.; Miravitlles, C. Supercritical carbonation of calcium aluminate cement. Cem. Concr. Res. 2008, 38, 1033-1037. [CrossRef]

47. He, P.; Zhang, B.; Lu, J.-X.; Poon, C.S. ASR expansion of alkali-activated cement glass aggregate mortars. Constr. Build. Mater. 2020, 261, 119925. [CrossRef]

48. Zhang, B.; He, P.; Poon, C.S. Optimizing the use of recycled glass materials in alkali activated cement (AAC) based mortars. $J$. Clean. Prod. 2020, 255, 120228. [CrossRef]

49. Panpa, W.; Jinawath, S.; Kashima, D.P. $\mathrm{Ag}_{2} \mathrm{O}-\mathrm{Ag} / \mathrm{CAC} / \mathrm{SiO}_{2}$ composite for visible light photocatalytic degradation of cumene hydroperoxide in water. J. Mater. Res. Technol. 2019, 8, 5180-5193. [CrossRef]

50. Hossain, S.K.S.; Roy, P.K. Development of waste derived nano-lakargiite bonded high alumina refractory castable for high temperature applications. Ceram. Int. 2019, 45, 16202-16213. [CrossRef]

51. Al-musawi, H.; Figueiredo, F.P.; Guadagnini, M.; Pilakoutas, K. Shrinkage properties of plain and recycled steel-fibre-reinforced rapid hardening mortars for repairs. Constr. Build. Mater. 2019, 197, 369-384. [CrossRef]

52. Al-musawi, H.; Figueiredo, F.P.; Bernal, S.A.; Guadagnini, M.; Pilakoutas, K. Performance of rapid hardening recycled clean steel fibre materials. Constr. Build. Mater. 2019, 195, 483-496. [CrossRef]

53. Yildırım, S.T.; Baynal, K.; Fidan, O. Internal Curing and Temperature Effect on Lightweight and Heat Insulated Mortar with Recycled Concrete Aggregate. Acta Phys. Pol. A 2019, 135, 865-869. [CrossRef] 
54. Kulu, P.; Goljandin, D.; Külaviir, J.; Hain, T.; Kivisto, M. Recycling of Niobium Slag by Disintegrator Milling. In Key Engineering Materials; Trans Tech Publications: Baech, Switzerland, 2019; Volume 799, pp. 97-102.

55. Ogrodnik, P.; Szulej, J.; Franus, W. The Wastes of Sanitary Ceramics as Recycling Aggregate to Special Concretes. Materials 2018, 11, 1275. [CrossRef] [PubMed]

56. Nematzadeh, M.; Dashti, J.; Ganjavi, B. Optimizing compressive behavior of concrete containing fine recycled refractory brick aggregate together with calcium aluminate cement and polyvinyl alcohol fibers exposed to acidic environment. Constr. Build. Mater. 2018, 164, 837-849. [CrossRef]

57. Nematzadeh, M.; Baradaran-Nasiri, A. Residual properties of concrete containing recycled refractory brick aggregate at elevated temperatures. J. Mater. Civ. Eng. 2018, 30, 4017255. [CrossRef]

58. Baradaran-Nasiri, A.; Nematzadeh, M. The effect of elevated temperatures on the mechanical properties of concrete with fine recycled refractory brick aggregate and aluminate cement. Constr. Build. Mater. 2017, 147, 865-875. [CrossRef]

59. Stonys, R.; Kuznetsov, D.; Krasnikovs, A.; Škamat, J.; Baltakys, K.; Antonovič, V.; Černašejus, O. Reuse of ultrafine mineral wool production waste in the manufacture of refractory concrete. J. Environ. Manag. 2016, 176, 149-156. [CrossRef]

60. Navarro-Blasco, Í.; Fernández, J.M.; Duran, A.; Sirera, R.; Alvarez, J.I. A novel use of calcium aluminate cements for recycling waste foundry sand (WFS). Constr. Build. Mater. 2013, 48, 218-228. [CrossRef]

61. Fernández, L.J.; Ferrer, R.; Aponte, D.F.; Fernandez, P. Recycling silicon solar cell waste in cement-based systems. Sol. Energy Mater. Sol. cells 2011, 95, 1701-1706. [CrossRef]

62. Chen, L.; Wang, Y.-S.; Wang, L.; Zhang, Y.; Li, J.; Tong, L.; Hu, Q.; Dai, J.-G.; Tsang, D.C.W. Stabilisation/solidification of municipal solid waste incineration fly ash by phosphate-enhanced calcium aluminate cement. J. Hazard. Mater. 2021, 408, 124404. [CrossRef] [PubMed]

63. Erans, M.; Jeremias, M.; Zheng, L.; Yao, J.G.; Blamey, J.; Manovic, V.; Fennell, P.S.; Anthony, E.J. Pilot testing of enhanced sorbents for calcium looping with cement production. Appl. Energy 2018, 225, 392-401. [CrossRef]

64. Xu, L.; Wang, P.; Wu, G.; Li, N. Effect of calcium aluminate cement on hydration properties and microstructure of portland cement. Materials 2015, 13, 4000.

65. Akiti, T.T., Jr.; Constant, K.P.; Doraiswamy, L.K.; Wheelock, T.D. An improved core-in-shell sorbent for desulfurizing hot coal gas. Adv. Environ. Res. 2002, 6, 419-428. [CrossRef]

66. Akiti, T.T., Jr.; Constant, K.P.; Doraiswamy, L.K.; Wheelock, T.D. Development of an advanced calcium-based sorbent for desulfurizing hot coal gas. Adv. Environ. Res. 2001, 5, 31-38. [CrossRef]

67. Lv, H.; Xie, M.; Shi, L.; Zhao, H.; Wu, Z.; Li, L.; Li, R.; Liu, F. A novel green process for the synthesis of high-whiteness and ultrafine aluminum hydroxide powder from secondary aluminum dross. Ceram. Int. 2022, 48, 953-962. [CrossRef]

68. Shakor, P.; Nejadi, S.; Paul, G.; Sanjayan, J. A novel methodology of powder-based cementitious materials in 3D inkjet printing for construction applications. In Proceedings of the Sixth International Conference on Durability of Concrete Structures (ICDCS 2018), Leeds, UK, 18-20 July 2018.

69. Shakor, P.; Sanjayan, J.; Nazari, A.; Nejadi, S. Modified 3D printed powder to cement-based material and mechanical properties of cement scaffold used in 3D printing. Constr. Build. Mater. 2017, 138, 398-409. [CrossRef]

70. Antonovič, V.; Pundiene, I.; Stonys, R.; Česniene, J.; Keriene, J. A review of the possible applications of nanotechnology in refractory concrete. J. Civ. Eng. Manag. 2010, 16, 595-602. [CrossRef]

71. Das, A.; Reiter, L.; Mantellato, S.; Flatt, R.J. Blended calcium aluminate cements for digital fabrication with concrete. In Proceedings of the 5th International Conference on Calcium Aluminates (2022), Cambridge, UK, 1-3 June 2020; ETH Zurich-Institute of Building Materials: Zurich, Switzerland, 2022. [CrossRef]

72. Bharati, S.; Sah, R.; Sambandam, M. Green Castable Using Steelmaking Slags: A Sustainable Product for Refractory Applications. J. Sustain. Metall. 2020, 6, 113-120. [CrossRef]

73. Giroudon, M.; Lavigne, M.P.; Patapy, C.; Bertron, A. Biodeterioration mechanisms and kinetics of SCM and aluminate based cements and AAM in the liquid phase of an anaerobic digestion. MATEC Web Conf. 2018, 199, 2003.

74. Moradllo, M.K.; Ley, M.T. Comparing ion diffusion in alternative cementitious materials in real time by using non-destructive X-ray imaging. Cem. Concr. Compos. 2017, 82, 67-79. [CrossRef]

75. Boden, T.; Andres, B.; Marland, G. Global, Regional, and National Fossil-Fuel $\mathrm{CO}_{2}$ Emissions (1751-2010); OSTI. GOV: Oak Ridge, TN, USA, 2013. [CrossRef]

76. Burris, L.E.; Alapati, P.; Moser, R.D.; Ley, M.T.; Berke, N.; Kurtis, K.E. Alternative cementitious materials: Challenges and opportunities. In Proceedings of the International Workshop on Durability and Sustainability of Concrete Structures, Bologna, Italy, 1-3 October 2015.

77. Henry-Lanier, E.; Szepizdyn, M.; Parr, C. Optimisation of the Environmental Footprint of Calcium-Aluminate-Cement Containing Castables. Refract. Worldforum 2015, 8, 81-86. 